\title{
Correction to: Exploring the Relationship \\ Between Lasting, Quality Social \\ Bonds and Intermittency in Offending
}

\author{
Christi Metcalfe ${ }^{1} \cdot$ Thomas Baker $^{2} \cdot$ Caitlin M. Brady $^{2}$ \\ Published online: 8 June 2019 \\ (C) Southern Criminal Justice Association 2019
}

\section{Correction to: American Journal of Criminal Justice (2019) https://doi.org/10.1007/s12103-019-09486-4}

The original version of this article, unfortunately, was missing a decimal point in Table 2. The effect size (b) for Proportion of Time on the Street in Waves 1-6 should be -2.403 instead of -2403 .

Publisher's Note Springer Nature remains neutral with regard to jurisdictional claims in published maps and institutional affiliations.

The online version of the original article can be found at https://doi.org/10.1007/s12103-019-09486-4

Christi Metcalfe

cmetcalfe@sc.edu

1 Department of Criminology and Criminal Justice, University of South Carolina, 1305 Greene Street, Columbia, SC 29208, USA

2 Department of Criminal Justice, University of Central Florida, 12494 University Blvd, Orlando, FL 32816, USA 